\title{
Magnetically stimulated ciprofloxacin release from polymeric microspheres entrapping iron oxide nanoparticles
}

This article was published in the following Dove Press journal:

International Journal of Nanomedicine

9 July 2015

Number of times this article has been viewed

\author{
Sirinrath Sirivisoot ${ }^{1}$ \\ Benjamin S Harrison ${ }^{2}$ \\ 'Biological Engineering Program, \\ Faculty of Engineering, King Mongkut's \\ University of Technology Thonburi, \\ Bangkok, Thailand; ${ }^{2}$ Wake Forest \\ Institute for Regenerative Medicine, \\ Wake Forest School of Medicine, \\ Wake Forest University Health \\ Sciences, Winston-Salem, NC, USA
}

\begin{abstract}
To extend the external control capability of drug release, iron oxide nanoparticles (NPs) encapsulated into polymeric microspheres were used as magnetic media to stimulate drug release using an alternating magnetic field. Chemically synthesized iron oxide NPs, maghemite or hematite, and the antibiotic ciprofloxacin were encapsulated together within polycaprolactone microspheres. The polycaprolactone microspheres entrapping ciprofloxacin and magnetic NPs could be triggered for immediate drug release by magnetic stimulation at a maximum value of $40 \%$. Moreover, the microspheres were cytocompatible with fibroblasts in vitro with a cell viability percentage of more than $100 \%$ relative to a nontreated control after 24 hours of culture. Macrophage cell cultures showed no signs of increased inflammatory responses after in vitro incubation for 56 hours. Treatment of Staphylococcus aureus with the magnetic microspheres under an alternating (isolating) magnetic field increased bacterial inhibition further after 2 days and 5 days in a broth inhibition assay. The findings of the present study indicate that iron oxide NPs, maghemite and hematite, can be used as media for stimulation by an external magnetic energy to activate immediate drug release.
\end{abstract}

Keywords: antibacterial, maghemite, hematite, Staphylococcus aureus

\section{Introduction}

Magnetic nanoparticles (NPs) are potentially powerful biocompatible materials applicable for use in various biomedical applications, ranging from diagnostics (contrast enhancement for magnetic resonance imaging) to therapeutics (potential drug delivery vehicles and hyperthermia agents), as well as cell/protein separation and biosensors. ${ }^{1-3}$ Among magnetic NPs for biomedical applications, iron oxide NPs are particularly attractive because they exhibit ferromagnetism, low toxicity, and high biocompatibility with cells and tissues. ${ }^{4}$ Small iron oxide NPs (such as maghemite $\left[\gamma-\mathrm{Fe}_{2} \mathrm{O}_{3}\right]$, hematite $\left[\alpha-\mathrm{Fe}_{2} \mathrm{O}_{3}\right]$, magnetite $\left[\mathrm{Fe}_{3} \mathrm{O}_{4}\right]$, and other ferrites) exhibit a large magnetic moment that is useful for guiding them to a specific tissue or organ by an external magnetic field. ${ }^{5}$ Iron oxide magnetic NPs are used as magnetically activated materials to externally control drug release from nanocomposite membranes, ${ }^{6}$ liposomes, ${ }^{7}$ microspheres,${ }^{8,9}$ microcapsules, ${ }^{10}$ and nanospheres, ${ }^{11,12}$ typically by mechanical disruption of the biomaterial matrix-embedded drugs. Iron oxide is also used to magnetically control or target the delivery of anticancer drugs (eg, paclitaxel/rapamycin, ${ }^{13}$ doxorubicin ${ }^{14}$ ) and antibiotics (eg, gentamicin ${ }^{15}$ ). Therefore, magnetic targeting using iron oxide NPs containing antibiotics can be localized to pathologic sites by an external magnet to inhibit bacterial growth.

The enormous advantages and wide array of functions that can be designed into polymeric systems have encouraged biomedical scientists to use polymers for drug 
delivery, ${ }^{16,17}$ tissue engineering, ${ }^{18}$ and biologic imaging. ${ }^{19}$ Natural polymers that can degrade into biologically compatible components under physiologic conditions present an attractive alternative for the development of drug delivery systems. Entrapping a drug within a suitable carrier can enhance the aqueous solubility of the drug, increase its circulation half-life, target the drug to certain tissues, and improve tissue penetration of the drug. These features can increase drug bioavailability to diseased tissues, while at the same time decrease drug toxicity to the healthy tissue, thus improving therapeutic efficacy. Polycaprolactone (PCL) is a biocompatible and biodegradable polymer (Food and Drug Administration approved) that undergoes chemical degradation through random hydrolysis of ester bonds, constituting the backbone of polymer chains. PCL creates an acid-free environment during degradation, unlike polylactide or polyglycolide. ${ }^{20}$ PCL possesses hydrophobicity and high permeability to low molecular-weight drugs $^{21}$ and has been used to deliver various drugs, such as anticancer drugs (eg, taxol $\left.{ }^{22}\right)$, anti-inflammatory agents (eg, sulfasalazine/betamethasone ${ }^{23}$ ), and proteins (eg, bovine serum albumin ${ }^{24}$ ), as well as long-term implants and adhesive barriers. In the present study, we investigated the potential of using a magnetically stimulated antibiotic delivery system of PCL microspheres containing iron oxide NPs and ciprofloxacin (CIP) - to treat Staphylococcus aureus, which commonly contaminates bone implants.

Infection of biomaterial implants is a major cause of implant failure. Biomaterial-associated infection can develop from perioperative bacterial contamination of implant surfaces during implantation, immediately post surgery during hospitalization, or by hematogenous spreading of bacteria from infections elsewhere in the body. ${ }^{25} \mathrm{~S}$. aureus is the most frequently isolated pathogen from biomaterial implant surfaces, detected in $\sim 23 \%$ of infections associated with prosthetic joints. ${ }^{26}$

CIP is used to treat bacterial infections in human beings (such as urinary tract, gastrointestinal, and skin/bone infections). ${ }^{27}$ It is the most widely used fluoroquinolone for bacterial bone infections and has potent bactericidal activity against a broad range of clinically relevant Gram-negative and Gram-positive pathogens. ${ }^{28}$ The minimum inhibitory concentration (MIC) of CIP is as low as $0.25-1 \mu \mathrm{g} / \mathrm{mL}$ for Staphylococcus (frequently found in osteomyelitis). ${ }^{29}$ Although the usual dosage of CIP is $750 \mathrm{mg}$ twice daily for periods ranging from 6 weeks to several months, the cure rate is only $\sim 56 \%$. $^{30}$ Therefore, there is still a need to develop a local and externally controllable release system for immediate antibiotic treatment of infected bone implants.
Our work provides a method to embed CIP and iron oxide NPs (either maghemite $\left[\gamma-\mathrm{Fe}_{2} \mathrm{O}_{3}\right]$ or hematite $\left[\alpha-\mathrm{Fe}_{2} \mathrm{O}_{3}\right]$ ) in PCL microspheres. The CIP was released from the microspheres using an alternating (oscillating) magnetic field (AMF) to suppress the growth of $S$. aureus. Our hypothesis was that the application of an AMF toward the PCL microspheres entrapping magnetic NPs and antibiotics would trigger faster drug release to achieve a higher local concentration of the drug and eliminate bacteria at the bone implant surface. In addition, we evaluated the fibroblast compatibility and macrophage inflammatory response under standard cell culture conditions in the present study. This study provides a proof of concept of stimulated antibiotic release using a magnetic field, which could be useful for further studies of externally controlled drug delivery devices for bone implants.

\section{Materials and methods Synthesis of iron oxide NPs}

Iron oxide NPs were synthesized by coprecipitation of iron salts. Briefly, ferrous chloride $\left(\mathrm{FeCl}_{2} \cdot 4 \mathrm{H}_{2} \mathrm{O}\right.$; Thermo Fisher Scientific, Waltham, MA, USA) and ferric chloride $\left(\mathrm{FeCl}_{3} \cdot 6 \mathrm{H}_{2} \mathrm{O}\right.$; Thermo Fisher Scientific) in a molar ratio of $1: 2$ were dissolved in $50 \mathrm{~mL}$ of distilled water in the presence of $0.4 \mathrm{~N}$ hydrochloric acid ( $\mathrm{HCl}$; Thermo Fisher Scientific) and degassed with nitrogen gas. The solution was dropped into $40 \mathrm{~mL}$ of ammonium hydroxide $\left(\mathrm{NH}_{4} \mathrm{OH}\right.$; Sigma-Aldrich Co., St Louis, MO, USA) under a nitrogen blanket. The solution of iron oxide NPs was heated to $90^{\circ} \mathrm{C}$ for 30 minutes under magnetic stirring and aeration. The solution was centrifuged at $4,750 \mathrm{rpm}$ for 10 minutes. The iron oxide NPs were decanted, diluted with distilled water, and dispersed by vortexing. The cleaning process with water was repeated three times. Before the spray-drying process, $0.5 \mathrm{M}$ citric acid (Sigma-Aldrich Co.) was added to the solution of iron oxide NPs to increase NP dispersion. The iron oxide NPs were then spray-dried using a Mini Spray Dryer B-290 (BÜCHI, Flawil, Switzerland) at an inlet temperature of $170^{\circ} \mathrm{C}$.

\section{Drug encapsulation (oil-in-water emulsion)}

PCL (Cat\# 19561, $M_{\mathrm{n}} \sim 43-50 \mathrm{k}$; Polysciences, Inc., Warrington, PA, USA) was dissolved at $5 \% \mathrm{w} / \mathrm{v}$ in chloroform (SigmaAldrich Co.). Then, $2 \mathrm{~mL}(140 \mathrm{mg} / \mathrm{mL})$ of maghemite (nonspray-dried NPs) fluid or $380 \mathrm{mg}$ of the hematite (spraydried NPs) was added to the organic solution and vortexed for 10 minutes. Next, 4.5 mM CIP (Sigma-Aldrich Co.) was added to $10 \mathrm{~mL}$ of the organic solution and vortexed for 
10 minutes. The organic mixture was poured into a mixture of $0.5 \% \mathrm{w} / \mathrm{v}$ polyvinyl alcohol (Sigma-Aldrich Co.) and distilled water. The mixture was sonicated using a Model 100 Sonic Dismembrator (Thermo Fisher Scientific) for 10 minutes at the room temperature. The PCL-CIP-NP microspheres were collected from the emulsified solution by centrifugation at 4,750 rpm. The microspheres were then decanted, diluted with distilled water, and centrifuged at 4,750 rpm three times. The microspheres were then dispersed in phosphate-buffered saline (PBS; $1 \mathrm{M}, \mathrm{pH} 7.4$ ) at a concentration of $40 \mu \mathrm{g} / \mathrm{mL}$ and gamma irradiated at $1 \mathrm{mrad}$ before the cell culture and bacterial inhibition studies.

\section{Nano- and microparticle characterizations}

The PCL-CIP-NP microspheres were characterized using a Fourier transform infrared spectrometer (Spectrum 400; PerkinElmer Inc., Waltham, MA, USA) equipped with a universal attenuated total reflectance sampling accessory (PerkinElmer Inc.). The samples were also measured by dynamic light scattering (DLS) measurements. The DLS measurements were performed on a Zetasizer Nano S (Malvern Instruments, Malvern, UK) equipped with an $\mathrm{HeNe}$ laser at $632.8 \mathrm{~nm}$ and a scattering detector at $173^{\circ} \mathrm{C}$ using water as a dispersant (refraction index $=1.33$ and viscosity $=0.8872$ ) at the room temperature with cumulants analysis. Raman spectra of the synthesized NPs were obtained using a Raman spectrometer (RamanStation 400; PerkinElmer Inc.) equipped with an excitation source of $350 \mathrm{~mW}$ near-infrared $785 \mathrm{~nm}$ laser. The spectra were obtained from $100 \mathrm{~cm}^{-1}$ to $1,800 \mathrm{~cm}^{-1}$ with a peak resolution of $4 \mathrm{~cm}^{-1}$. The solutions of NPs and PCL-CIP-NPs were dropped and dried overnight on carbon-coated Formvar 200 mesh copper grids (Ted Pella, Inc., Redding, CA, USA). The grids were visualized using a Philips $400120 \mathrm{keV}$ transmission electron microscope (TEM; Philips, Hillsboro, OR, USA) with a high-tilt goniometer stage.

\section{Cell culture and assay}

Mouse fibroblasts NIH/3T3 (CRL-1658, passage number =4-7; American Type Culture Collection (ATCC), Manassas, VA, USA) or mouse macrophage Raw 264.7 (TIB-71, passage number $=7-12$; ATCC) was seeded at a density of 40,000 cells $/ \mathrm{cm}^{2}$ in Dulbecco's Modified Eagle's Medium (HyClone, Logan, UT, USA) with 10\% bovine calf serum (HyClone) and 1\% penicillin/streptomycin (HyClone) and incubated under standard cell culture conditions $\left(37^{\circ} \mathrm{C}\right.$, $5 \% \mathrm{CO}_{2}$ in humidified atmosphere). After 4 hours of incubation, the solutions of samples (maghemite, hematite,
PCL-CIP-maghemite, and PCL-CIP-hematite) in deionized water were added to the cell culture media at concentrations of $4 \mu \mathrm{g} / \mathrm{mL}, 2 \mu \mathrm{g} / \mathrm{mL}, 1 \mu \mathrm{g} / \mathrm{mL}$, and $0.5 \mu \mathrm{g} / \mathrm{mL}$. The samples were further cultured with fibroblasts for 24 hours and with macrophages for 56 hours. The CellTiter $96^{\circledR}$ AQueous Non-Radioactive Cell Proliferation Assay (MTS; Promega Corporation, Fitchburg, WI, USA) was used to determine the cell viability of the fibroblasts and macrophages. The cell suspensions treated with the samples in triplicate were incubated with $500 \mu \mathrm{L}$ of $10 \% \mathrm{v} / \mathrm{v}$ MTS assay at $37^{\circ} \mathrm{C}$ for 3 hours. The formazan product, which was bioreduced from MTS by living cells, was read at an absorbance of $490 \mathrm{~nm}$ using a spectrophotometer (SpectraMax ${ }^{\circledR}$ M5; Molecular Devices LLC, Sunnyvale, CA, USA). Untreated cells were used as controls to calculate the percentages of cell viability. Experiments using both cell types were repeated three times. The media were changed every other day.

\section{Determination of MIC}

Stock solutions and dilutions were prepared according to the Clinical and Laboratory Standards Institute (M100S16 CLSI). ${ }^{31}$ The MIC was determined by broth and agar dilution tests. ${ }^{32}$ The MIC of CIP was defined as the lowest concentration inhibiting visible growth after incubation at $37^{\circ} \mathrm{C}$ for 24 hours with a shaker (speed at $220 \mathrm{rpm}$ ). Briefly, $S$. aureus (passage number $=3-4$, ATCC 2913) preserved in $20 \%$ glycerol and stored at $-80^{\circ} \mathrm{C}$ was purchased from the Cell and Virus Vector Core Laboratory (Wake Forest Baptist Medical Center, Winston-Salem, NC, USA). At the time of use, a frozen tube was thawed to make a streak plate. A sterilized $10 \mu \mathrm{m}$ loop was dipped into the bacterial tube and streaked onto a 5\% sheep blood agar plate (SBA plate; BD, Franklin Lakes, NJ, USA). The streaked plate was incubated for 24 hours under standard cell culture conditions $\left(37^{\circ} \mathrm{C}, 5 \%\right.$ $\mathrm{CO}_{2}$ in humidified air). The next day, the colony count plate was prepared and the MIC was determined. A single colony was lifted from the streak plate using a sterilized cottontipped applicator and dissolved with $5 \mathrm{~mL}$ sterilized PBS (HyClone) in a $14 \mathrm{~mL}$ glass tube with snap cap (BD). The bacterial suspension was adjusted to be equal to $10^{8} \mathrm{cfu} / \mathrm{mL}$ by comparison with the McFarland 0.5 turbidity standard (Thermo Fisher Scientific) and the addition of sterilized PBS. The bacterial suspension $\left(10^{8} \mathrm{cfu} / \mathrm{mL}\right.$ equivalent $)$ was diluted to $10^{5} \mathrm{cfu} / \mathrm{mL}$ with sterilized PBS and $10^{3} \mathrm{cfu} / \mathrm{mL}$ with Mueller-Hinton broth (BD), respectively. To prepare the colony count plate, $50 \mu \mathrm{L}$ of bacterial suspension $\left(10^{3} \mathrm{cfu} / \mathrm{mL}\right.$ equivalent) was pipetted onto an SBA plate and spread using an L-shape spreader (Thermo Fisher Scientific) and 
incubated in $37^{\circ} \mathrm{C}$ for 24 hours. The bacterial colonies were counted and recorded the next day. Then, the serial dilutions of $500 \mu \mathrm{g} / \mathrm{mL}$ of CIP in $0.1 \mathrm{~N} \mathrm{HCl}$ (stock solution) were prepared to a range of concentrations $(10-0.039 \mu \mathrm{g} / \mathrm{mL})$. The control group was a standard nutrient broth without CIP. Next, $10 \mu \mathrm{L}$ bacterial suspension $\left(10^{5} \mathrm{cfu} / \mathrm{mL}\right.$ equivalent in broth) was added to $10 \mathrm{~mL}$ of serial dilutions of CIP and a control tube. All tubes were incubated at $37^{\circ} \mathrm{C}$ for 24 hours with a shaker (220 rpm). A $100 \mu \mathrm{L}$ sample was obtained from the CIP-bacterial suspension and streaked onto SBA plates and incubated for 24 hours. The bacterial colonies were counted and recorded the next day. The study showed that the bacteria were inhibited by CIP at a concentration between $0.156 \mu \mathrm{g} / \mathrm{mL}$ and $0.31 \mu \mathrm{g} / \mathrm{mL}$. At a CIP concentration of $0.156 \mu \mathrm{g} / \mathrm{mL}$, bacterial colonies were too many to count $(>300)$ in the plate. At a concentration of $0.31 \mu \mathrm{g} / \mathrm{mL}$, there was only one colony. Therefore, an inhibited concentration at $50 \%\left(\mathrm{MIC}_{50}\right)$ of CIP for $S$. aureus used in the present study was $0.23 \mu \mathrm{g} / \mathrm{mL}$.

\section{Determination of CIP}

The percentage of drug encapsulation was investigated by measuring the absorbance of CIP in the PCL-CIP-NPs using a spectrophotometer (SpectraMax ${ }^{\circledR}$ M5) to determine the amount of CIP loaded within the microspheres at $270 \mathrm{~nm}$, a previously validated wavelength for determining CIP concentrations. ${ }^{33}$ Before the drug release study, the PCL-CIP-NP microspheres were purified by resuspension with PBS (1 M, $\mathrm{pH}$ 7.4) and centrifuged three times. A linear relationship
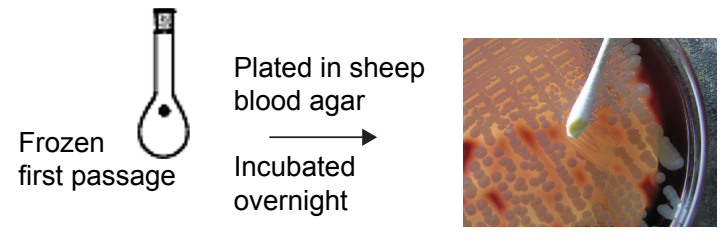

Diluted to $10^{8}$ with PBS

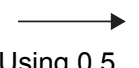

Using 0.5

McFarland standard
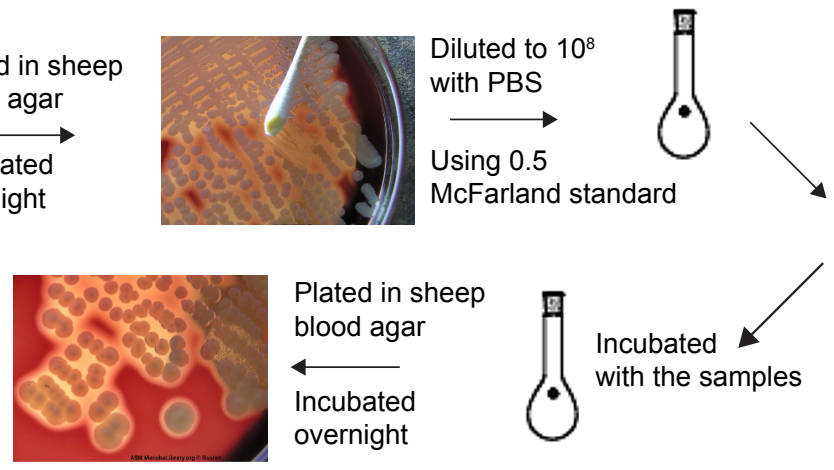

Diluted to $1: 10^{5}$ with sterile MuellerHinton broth

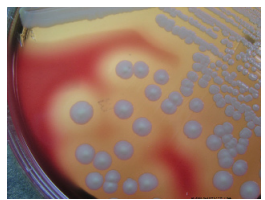

Made streak plate from the dilution of $1: 10^{3}$ with PBS and spread using L-shaped spreader and incubated overnight

Figure I Schematic of the bacteria study (Staphylococcus aureus, ATCC 292I3).

Notes: Bacteria colonies were counted, and the mean was calculated before incubation with PCL-maghemite, PCL-hematite, PCL-CIP-maghemite, PCL-CIP-hematite, or control (bacteria in broth). Bacteria $\left(I: 10^{5} \mathrm{cfu}\right)$ in the broth were cultured with particles for up to 5 days. At days I, 2, and 5 , bacteria were plated in sheep blood agar plates and incubated overnight, and the colonies were counted.

Abbreviations: PCL, polycaprolactone; CIP, ciprofloxacin; PBS, phosphate-buffered saline. 
model 1314 (Barnstead Intl. Lab-Line, Melrose Park, IL, USA) with an orbital diameter of 0.75 in at $220 \mathrm{rpm}$. The AMF was measured using a 5180 Gauss/Tesla Meter (FW Bell/Pacific Scientific-OECO, Milwaukie, OR, USA) at a height of $1 \mathrm{~cm}$ (approximately the mean height of a bacterial suspension in a $1.5 \mathrm{~mL}$ tube) above the bed magnet.

\section{In vitro drug release study}

To study the drug release, $2.4 \mu \mathrm{g}$ of microspheres were suspended in $1 \mathrm{~mL}$ of sterilized PBS (1 M, pH 7.4). The drug release study was performed at $37^{\circ} \mathrm{C}$ at a stirring rate of $220 \mathrm{rpm}$ in the presence of an AMF. A $100 \mu \mathrm{L}$ aliquot of the solution was sampled, and the absorbance was measured with a spectrophotometer (SpectraMax ${ }^{\circledR}$ M5) at $270 \mathrm{~nm}$ before replacing the aliquot back into the solution. Optical measurements were obtained daily on days $1-9$ and then at 19 days
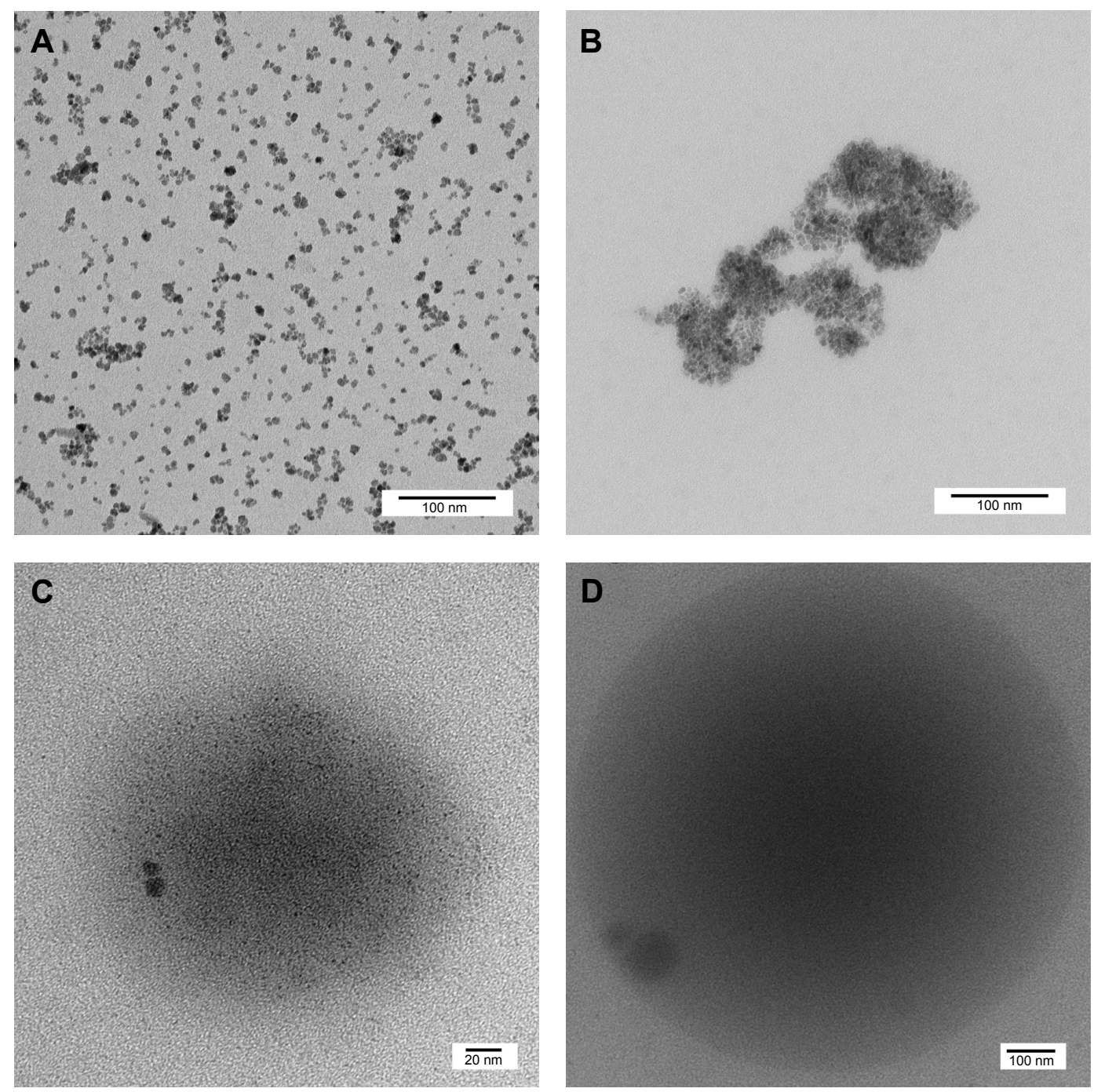

Figure 2 TEM micrographs of (A) maghemite (nonspray-dried iron oxide NPs), (B) hematite (spray-dried iron oxide NPs), (C) PCL-CIP-maghemite microsphere, and (D) PCL-CIP-hematite microsphere.

Abbreviations: TEM, transmission electron microscope; NPs, nanoparticles; PCL, polycaprolactone; CIP, ciprofloxacin. 
by coprecipitation of $\mathrm{Fe}^{2+}$ and $\mathrm{Fe}^{3+}$ aqueous chloride salt solution. $\mathrm{Fe}_{3} \mathrm{O}_{4}$ was obtained according to the following chemical equation: $\mathrm{Fe}^{2+}+2 \mathrm{Fe}^{3+}+8 \mathrm{OH}^{-} \rightarrow \mathrm{Fe}_{3} \mathrm{O}_{4}+4 \mathrm{H}_{2} \mathrm{O}$. To obtain the colloidal suspension of $\mathrm{Fe}_{2} \mathrm{O}_{3}$ (brown-red color), the aqueous $\mathrm{Fe}_{3} \mathrm{O}_{4}$ magnetic NPs were heated at $90^{\circ} \mathrm{C}$ for 30 minutes under aeration (nitrogen gas) to directly oxidize the magnetite (black color). ${ }^{34,35}$ Crystalline $\mathrm{Fe}_{2} \mathrm{O}_{3}$ is commonly obtained as either maghemite ( $\gamma$-phase) or hematite ( $\alpha$-phase). The Raman spectra results (Figure 3 ) confirmed that maghemite $\left(\gamma-\mathrm{Fe}_{2} \mathrm{O}_{3}\right)$ NPs changed to hematite $\left(\alpha-\mathrm{Fe}_{2} \mathrm{O}_{3}\right)$ by oxidation following the spray-drying process at $170^{\circ} \mathrm{C}$.

\section{Iron oxide NPs and drug encapsulation}

PCL microspheres entrapping the NPs and CIP were observed using TEM (Figure $2 \mathrm{C}$ and $\mathrm{D}$ ). The nonspray-dried iron oxide NPs were clearly observed throughout the PCL microspheres, whereas the spray-dried iron oxide NPs were observed as a group of aggregated NPs. Hematite was loaded near the wall of the PCL-CIP-hematite microspheres (Figure 2D). Furthermore, PCL-CIP-hematite was embedded in resin and sectioned (80-100 nm thick) before TEM imaging to confirm the presence of iron oxide particles in the middle of the microspheres (data not shown). The findings indicated iron oxide NPs in the middle of some PCL-CIP-hematite microspheres that could not be observed by TEM imaging of the whole microspheres alone, without sectioning. Attenuated total reflectance-Fourier transform infrared spectra of maghemite, hematite, PCL, CIP, PCL-CIP-maghemite, and PCL-CIP-hematite are shown in Figure 4. The results confirmed that NPs and CIP were successfully encapsulated inside the PCL microspheres.

The hydrodynamic size distribution of the samples measured using DLS and the mean diameter are shown in Figure 5A-D.

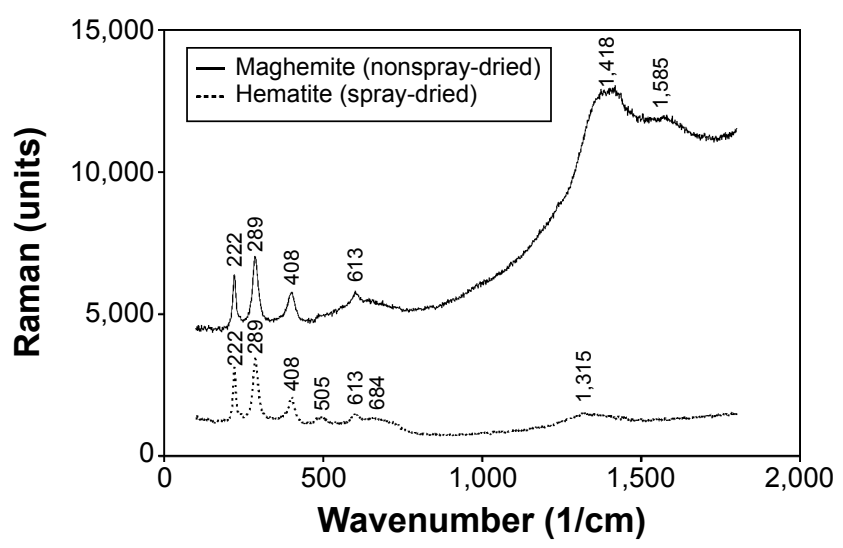

Figure 3 Raman spectra of maghemite $\left(\gamma-\mathrm{Fe}_{2} \mathrm{O}_{3}\right.$, nonspray-dried iron oxide NPs) and hematite ( $\alpha-\mathrm{Fe}_{2} \mathrm{O}_{3}$, spray-dried iron oxide NPs).

Abbreviation: NPs, nanoparticles.
The hydrodynamic diameters of the maghemite in deionized water ranged from $4.19 \mathrm{~nm}$ to $24.36 \mathrm{~nm}$, whereas the diameters of the hematite in deionized water ranged from $531.20 \mathrm{~nm}$ to $1,480 \mathrm{~nm}$ because the NPs aggregated during measurement. The hydrodynamic diameters of the PCL-CIP-maghemite and PCL-CIP-hematite ranged from $255 \mathrm{~nm}$ to $530 \mathrm{~nm}$ and from $190 \mathrm{~nm}$ to $1,110 \mathrm{~nm}$, respectively. The aggregation of hematite (Figure 2B) might contribute to the larger hydrodynamic diameters of the PCL-CIP-hematite microspheres, compared with the PCL-CIP-maghemite microspheres, after the encapsulation process.

\section{Bacterial inhibition study}

In this study, a bed magnet generated a weak AMF. The bacterial populations decreased in the presence of PCLCIP-maghemite, PCL-CIP-maghemite (AMF), PCL-CIPhematite, and PCL-CIP-hematite (AMF) in comparison with the two control groups (bacteria alone with and without AMF) on days 2 and 5 of the cultures (Figure 6). On day 5, the bacterial population was significantly decreased in the presence of all samples when compared with the control groups. The PCL-CIP-maghemite and PCL-CIP-hematite inhibited bacterial growth after 2 days and 5 days of culture, but the efficiency improved in the presence of a magnetic field. For the control group, the application of an AMF did not inhibit bacterial growth from days 1 to 5 . The findings from the broth inhibition assay suggest that the growth inhibition effects of PCL-CIP-NPs on S. aureus growth were enhanced in the presence of an AMF after 2 days and 5 days of incubation compared to the effects in the absence of AMF. The results from the bacterial inhibition study confirmed that CIP, antibiotic against $S$. aureus, was released from the PCL-CIP-NP microspheres.

The bioavailability of CIP is reduced by $50 \%$ when coadministered with iron compound. ${ }^{36}$ Masadeh et al reported that the use of iron oxide NPs $\left(\mathrm{Fe}_{2} \mathrm{O}_{3}\right)$ in combination with CIP almost abolished its inhibitory effects on bacterial planktonic growth and biofilm formation. ${ }^{37}$ However, S. aureus was not included in that study. Another study demonstrated that Escherichia coli growth increased after $\gamma-\mathrm{Fe}_{2} \mathrm{O}_{3}$ treatment. ${ }^{38}$ Azam et al reported that $\mathrm{Fe}_{2} \mathrm{O}_{3}$ NPs exhibited the least bactericidal activity when compared with zinc oxide NPs, copper (II) oxide NPs, and tetracycline (standard antibiotics) against $S$. aureus. ${ }^{39}$ We also observed higher bacterial growth after treatment with maghemite $\left(\gamma-\mathrm{Fe}_{2} \mathrm{O}_{3}\right)$, hematite $\left(\alpha-\mathrm{Fe}_{2} \mathrm{O}_{3}\right)$, PCL-maghemite, and PCL-hematite after 2 days of culture when compared to PCL-CIP-maghemite and PCL-CIP-hematite (data not shown). Importantly, the 
A
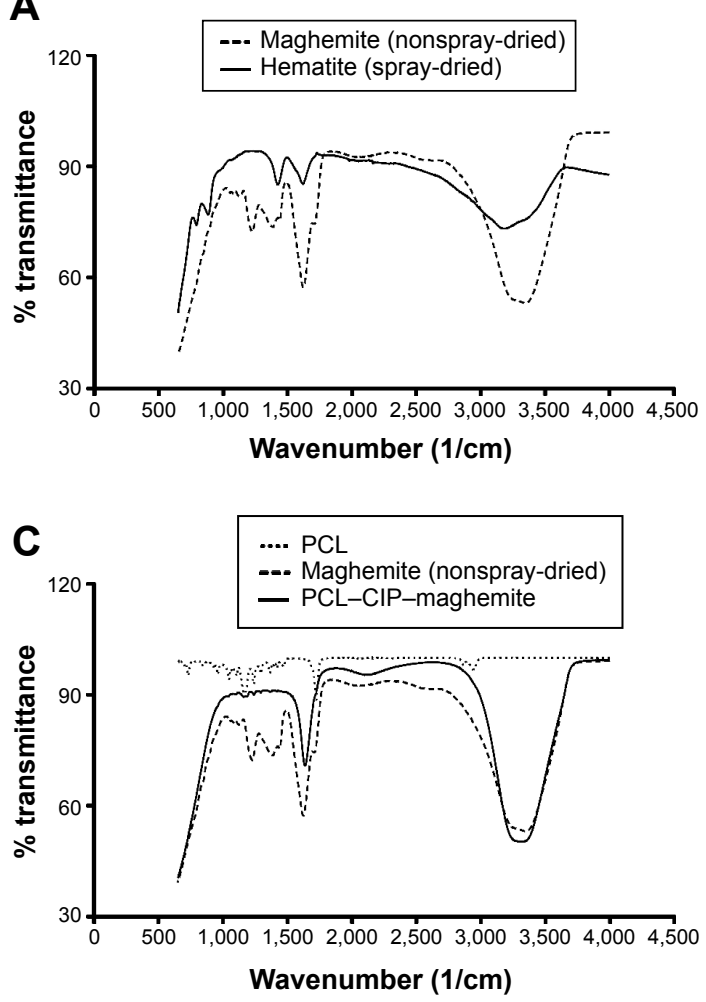

B
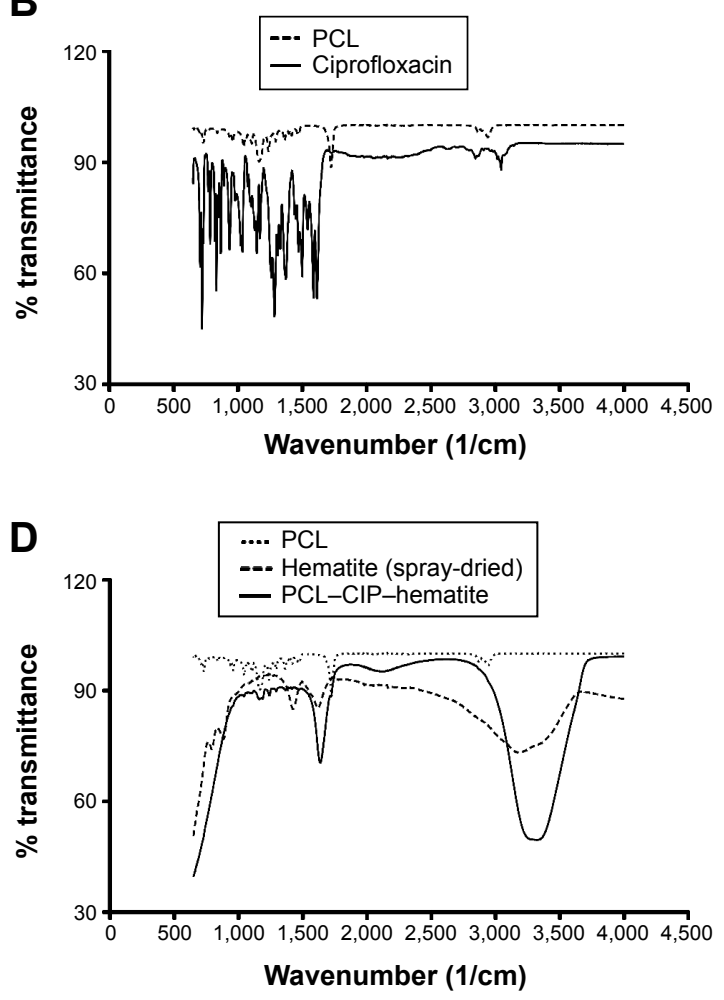

Figure 4 ATR-FTIR spectra of (A) maghemite (nonspray-dried iron oxide NPs) and hematite (spray-dried iron oxide NPs), (B) PCL and CIP, (C) PCL-CIP-maghemite microspheres, and (D) PCL-CIP-hematite microspheres.

Abbreviations: ATR-FTIR, attenuated total reflectance-Fourier transform infrared; NPs, nanoparticles; PCL, polycaprolactone; CIP, ciprofloxacin.
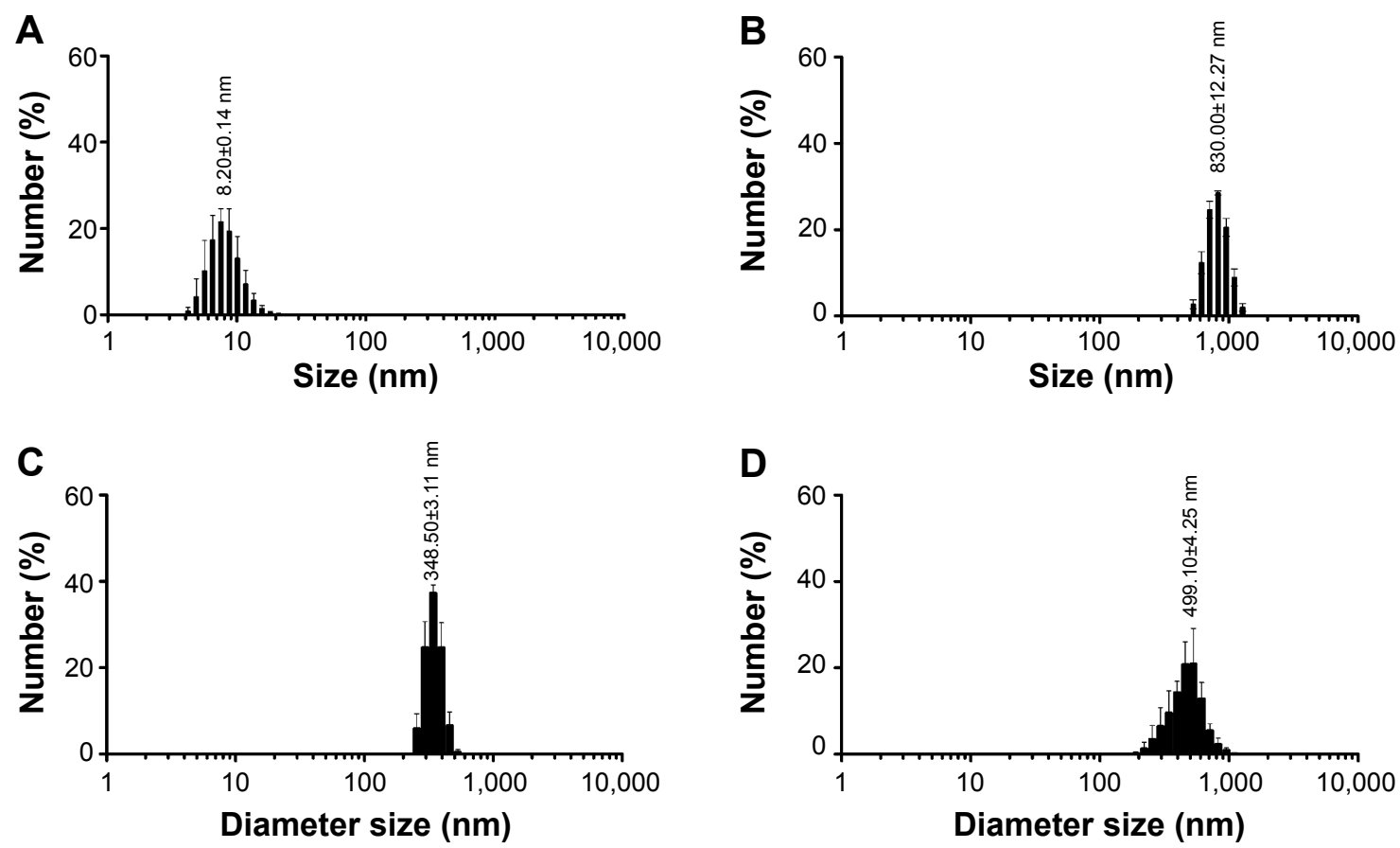

Figure 5 Histograms of the hydrodynamic size distribution of $(\mathbf{A})$ maghemite $\left(\gamma-\mathrm{Fe}_{2} \mathrm{O}_{3}\right.$, nonspray-dried $\left.\mathrm{NPs}\right),(\mathbf{B})$ hematite $\left(\alpha-\mathrm{Fe} \mathrm{O}_{3}\right.$, spray-dried iron oxide $\left.\mathrm{NPs}\right)$, $(\mathbf{C})$ PCL-CIP-maghemite, and (D) PCL-CIP-hematite.

Note: Values are mean \pm standard error of the mean; $N=3$.

Abbreviations: NPs, nanoparticles; PCL, polycaprolactone; CIP, ciprofloxacin. 

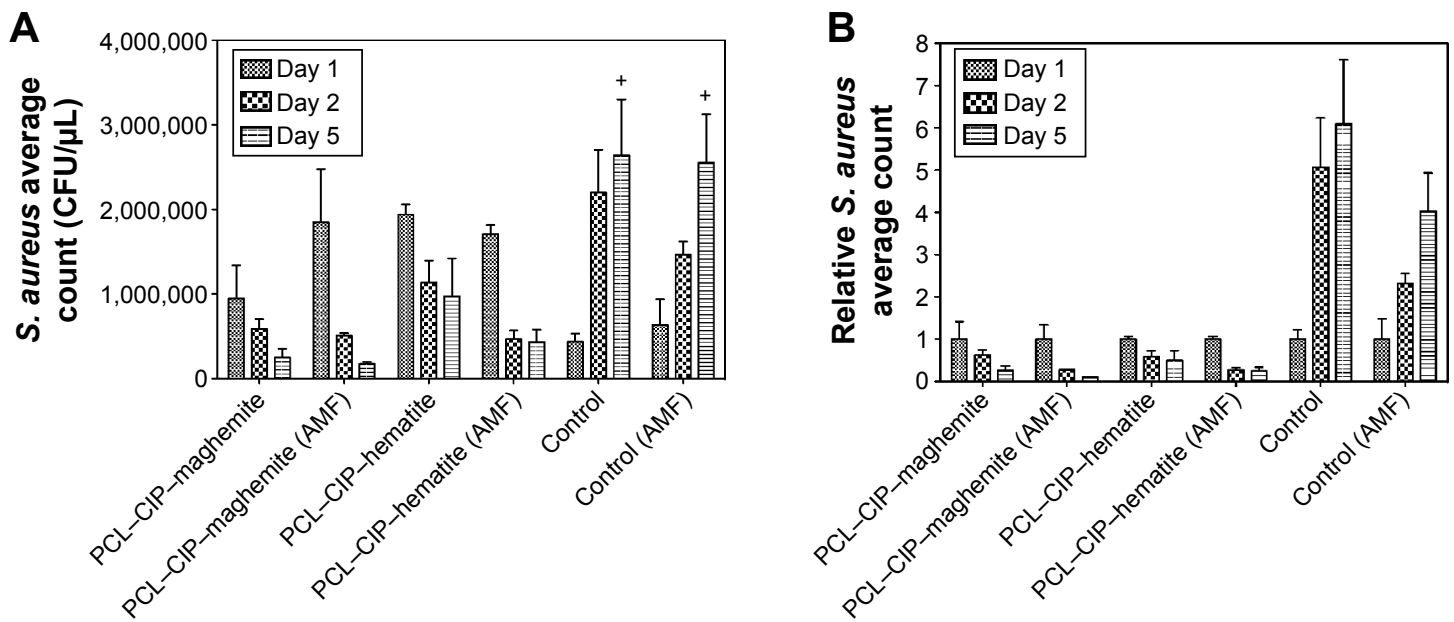

Figure 6 Staphylococcus aureus in broth inhibition assay in $(\mathbf{A})$ mean count (cfu/mL) and $(\mathbf{B})$ relative count with the treatments of PCL-CIP-maghemite and PCL-CIPhematite microspheres, and those in combination with AMF.

Notes: Controls were bacteria in broth without any treatment. Data are represented at days I, 2, and 5 of incubation. Values are mean \pm standard error of the mean; $n=3$, and $P$-values were calculated using one-way ANOVA with post hoc Tukey's test. ${ }^{+} P<0.05$ when compared with the data at day 5 of the samples, including PCL-CIP-hematite, PCL-CIP-maghemite, and PCL-CIP-maghemite with AMF.

Abbreviations: PCL, polycaprolactone; CIP, ciprofloxacin; AMF, alternating magnetic field; ANOVA, analysis of variance.

results of the present study suggested that treatment with PCL-CIP-maghemite and PCL-CIP-hematite containing $\mathrm{MIC}_{50}$ of CIP inhibited $S$. aureus growth after 2 days and 5 days of culture, and the inhibitory effects were stronger when applied with AMF.

Rakshit et al reported an adsorption mechanism of CIP on $\mathrm{Fe}_{3} \mathrm{O}_{4} \mathrm{NPs}$ via inner-sphere complexation and suggested that the adsorption was a $\mathrm{pH}$-dependent binding of the carboxyl functional group of CIP on $\mathrm{Fe}_{3} \mathrm{O}_{4} \mathrm{NPs} .{ }^{40}$ Tang et al suggested that CIP adsorption on reduced graphene oxide $\left(\mathrm{Fe}_{3} \mathrm{O}_{4}\right)$ was relatively high at $\mathrm{pH}$ 5.0-7.0, and the dominant mechanisms in the sorption were $\pi-\pi$ electron interaction and electrostatic repulsions..$^{41}$ Although the present study did not investigate the adsorption mechanism of CIP on maghemite or hematite, we hypothesize that CIP could interact with iron oxide NPs during the polymer encapsulation process and/or partial PCL degradation and may alter the antibacterial property of CIP toward S. aureus.

\section{Fibroblast and macrophage proliferation}

The percentages of fibroblast (24 hours) and macrophage (56 hours) viability are shown in Figure 7A and B, respectively. Fibroblast viability after treatment with the samples was more than $100 \%$ compared with the control (polystyrene). When the concentration of sample treatments was decreased from $4 \mu \mathrm{g} / \mathrm{mL}$ to $0.5 \mu \mathrm{g} / \mathrm{mL}$, the fibroblast viability increased in all sample groups. Specifically, fibroblast viability was significantly increased in the presence of PCL-CIP-hematite compared with that in the presence of maghemite, hematite, and PCL-CIP-maghemite with particle concentrations of $1 \mu \mathrm{g} / \mathrm{mL}$ and $0.5 \mu \mathrm{g} / \mathrm{mL}$. Macrophage viability was also more than $100 \%$ compared with the control (Figure 7B). The results revealed no significant differences in the macrophage cultures among the groups of samples after 56 hours. The results of both cell cultures confirmed the biocompatibility of the chemically synthesized iron oxide NPs and PCL-CIP-NPs at concentrations of $0.5-4 \mu \mathrm{g} / \mathrm{mL}$ with fibroblasts in vitro. These findings also suggest that iron oxide NPs and PCL-CIP-NPs do not cause macrophages (inflammatory cells) to grow aggressively during the early stage of cell culture (56 hours), and cell viability was similar to that of the control (polystyrene).

\section{In vitro drug release study}

A schematic representation of the PCL-CIP-NPs is shown in Figure 8A. The CIP release profiles of the PCL-CIPNPs were determined after incubation under an AMF. The magnetic flux density (magnetic field) in Gauss was plotted vs time in seconds during rotation, as shown in Figure 8B. This figure shows the maximum field range of $10 \mathrm{G}$ and the minimum field range of $-5 \mathrm{G}$. The release profiles of the PCL-CIP-NPs in PBS (1 M, pH 7.4) with or without the application of an AMF are shown in Figure 8C and D. All samples exhibited a considerable amount of drug release immediately after incubation with a rotation rate of $225 \mathrm{rpm}$ after 1 day. The percentage of drug release at day 1 from the PCL-CIP-maghemite was $\sim 51 \%$, that from the PCLCIP-maghemite with an AMF was $\sim 78 \%$, and that from 

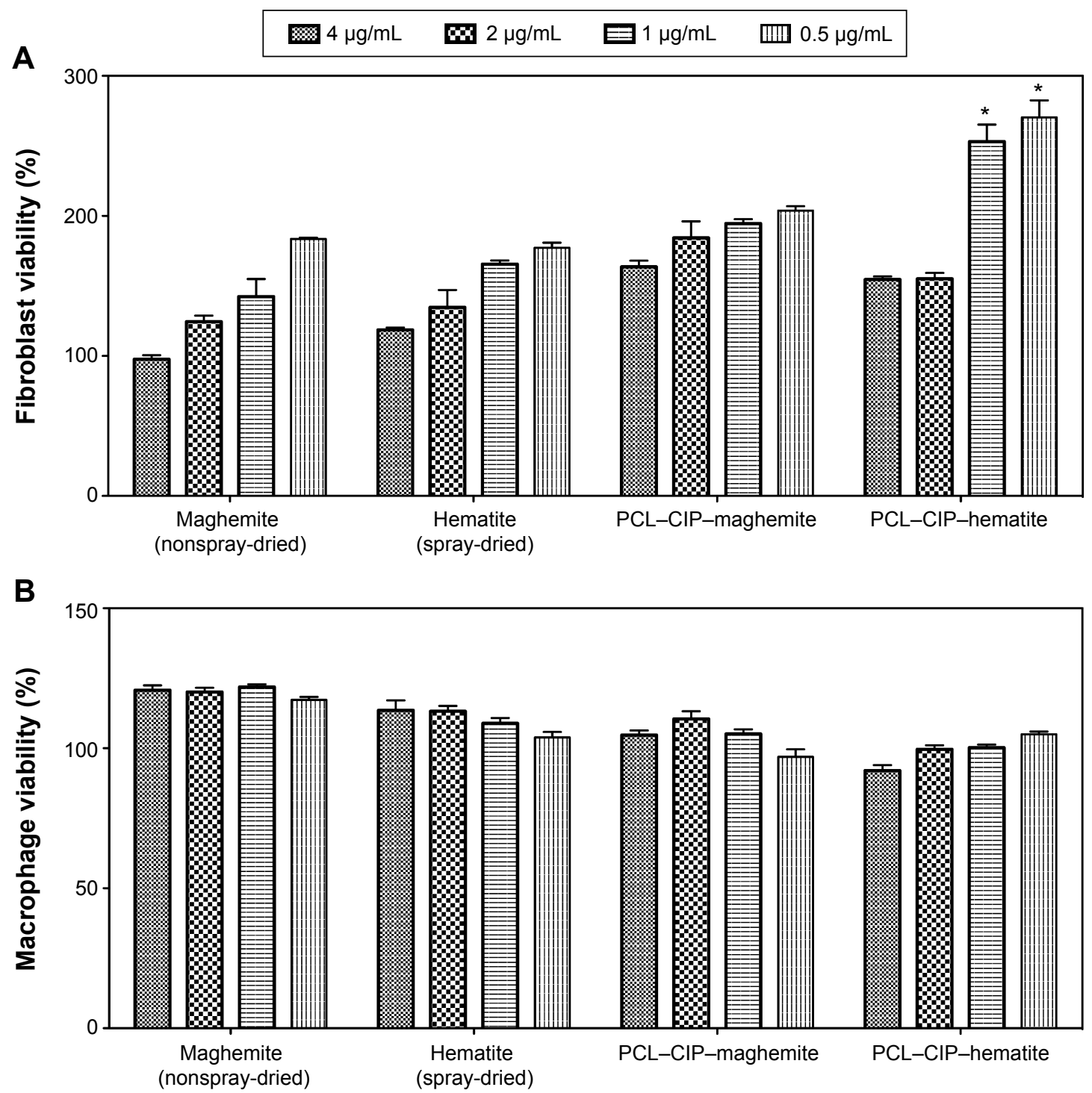

Figure 7 Fibroblast and macrophage viability was analyzed using an MTS assay in the presence of maghemite, hematite, PCL-CIP-maghemite, and PCL-CIP-hematite. Notes: (A) Fibroblasts were cultured for I day to assess cell viability and (B) macrophages were incubated for 56 hours to assess the inflammation response. The percentages were calculated based on the control group (without any particles). Values are mean \pm standard error of the mean; $n=3$. The $P$-values were calculated using a one-way ANOVA with post hoc Tukey's test. $* P<0.05$ when compared with maghemite, hematite, and PCL-CIP-maghemite at the same concentration.

Abbreviations: PCL, polycaprolactone; CIP, ciprofloxacin; ANOVA, analysis of variance.

the PCL-CIP-hematite both with and without an AMF was almost the same, $\sim 36 \%$ and $\sim 39 \%$, respectively. The results indicated that the immediate release of CIP from PCL-CIP-NP microspheres was increased by $\sim 27 \%$ in the presence of an AMF for PCL-CIP-maghemite and $~ 3 \%$ for PCL-CIP-hematite.

PCL degradation occurs very slowly over more than a year. ${ }^{42,43}$ The degradation process of PCL first proceeds via surface or bulk degradation, which involved hydrolytic cleavage of the polymer backbone only at the surface. ${ }^{42}$ Such initial hydration occurs in the first 6 months. No weight loss of PCL (molecular weight $\sim 20-50 \mathrm{kD}$ ) is observed during the initial (or partial) phase of the biodegradation process. ${ }^{43}$
Bosworth and Downes studied in vitro degradation behavior of the PCL fibers in PBS at $37^{\circ} \mathrm{C}$ at $\mathrm{pH} 7.4 .^{44}$ Their findings from high-performance liquid chromatography analysis revealed that PCL became more hydrophobic and, hence, is more likely to comprise longer length chains. A slight increase in the degradation by-products (no significant difference over 90 days) was detected, however, and may have been accelerated by autocatalysis occurring secondary to the accumulation of acidic breakdown products. Moreover, the results in that study from electrospray-mass spectrometry confirmed that PCL fibers underwent partial bulk degradation over 90 days. Because PCL has a very long degradation time (months), the absorbance values measured at $270 \mathrm{~nm}$ 
A

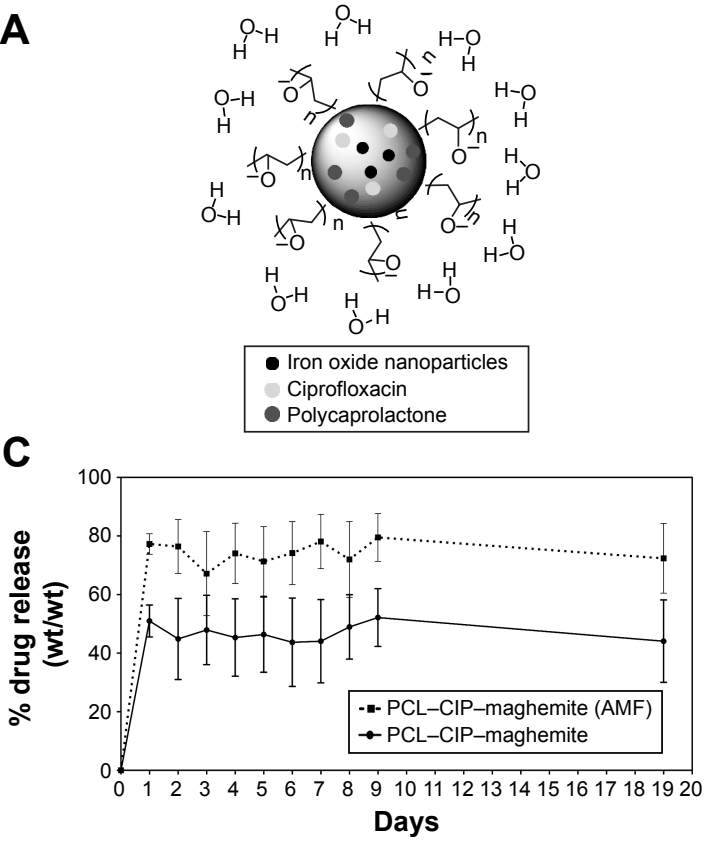

B

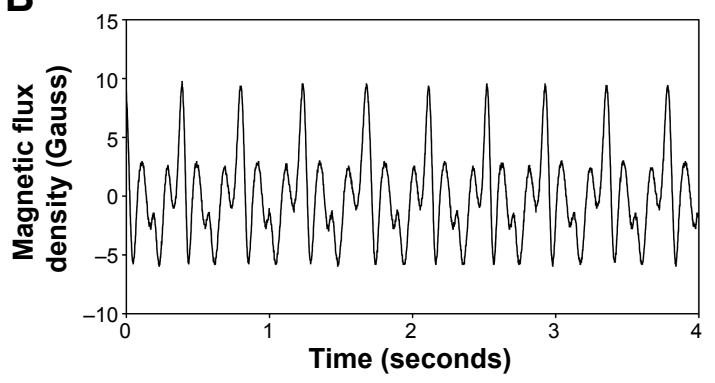

D

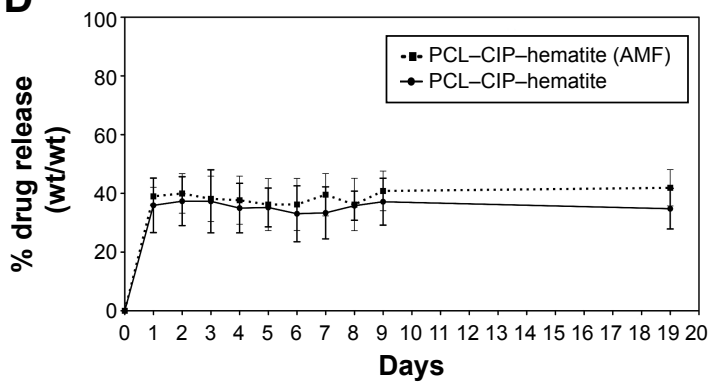

Figure 8 (A) Schematics of PCL, maghemite or hematite, and CIP in the oil sphere and water phases. (B) AMF was generated using a bed magnet placed on a laboratory rotator (orbital diameter $=0.75$ in) at $220 \mathrm{rpm}$. The suspension of bacteria and PCL-CIP-maghemite or PCL-CIP-hematite microspheres was incubated in the presence of AMF to study the release of CIP from the PCL-CIP-maghemite and PCL-CIP-hematite microspheres. (C, D) Representative curves of the percentage of CIP released from PCL-CIP-maghemite and PCL-CIP-hematite microspheres with and without AMF in PBS (I M, pH 7.4). The microspheres were incubated at $37^{\circ} \mathrm{C}$ for up to I9 days. Values are mean \pm standard error of mean; $n=3$.

Abbreviations: PCL, polycaprolactone; CIP, ciprofloxacin; AMF, alternating magnetic field; PBS, phosphate-buffered saline.

in the present study should only be due to the CIP at the observed time scale.

In a previous study, CIP was conjugated to the hydroxyl ends of polyesters, which were synthesized using caprolactone or polyethylene glycol (PEG) as initiators. ${ }^{45}$ Degradation of the polymer then occurred at $37^{\circ} \mathrm{C}$ in an aqueous buffered solution at $\mathrm{pH} 7.4$, and the CIP release was quantified by UV-Vis spectrophotometry at $277 \mathrm{~nm}$. The conjugated drug release rate with PEG was more than that with caprolactone for monomers and initiators. The addition of PEG, which is a hydrophilic initiator, accelerates the drug release rate (29\% CIP after 35 days at $\mathrm{pH} 7.4$ ) than the addition of caprolactone. Another study showed that CIP release from the PCL matrix soaking in PBS at pH 7.4 at $80^{\circ} \mathrm{C}$ and $150^{\circ} \mathrm{C}$ was remarkably slow, with $<5 \%$ release after 56 days. ${ }^{46}$ The findings suggested that the slow release was due to the slow degradation of PCL. Furthermore, in that study, PCL was activated with $5 \mathrm{M} \mathrm{NaOH}$ for 72 hours at $20^{\circ} \mathrm{C}$ to resemble in vivo behavior before the PCL degradation study; yet, no change was observed during the first 7 days and $<10 \%$ weight loss was detected after 82 days. Another previous study soaked PCL scaffolds under simulated physiologic conditions (PBS at $37^{\circ} \mathrm{C}$ ), in which PCL scaffolds treated with $\mathrm{NaOH}$ for 24 hours showed only a $20 \%$ weight loss after about 4 years of incubation. ${ }^{47}$ Evidence from many previous studies suggests that PCL did not likely interfere with the absorbance measurement of CIP at $270 \mathrm{~nm}$ in the present study, because PCL does not readily degrade for up to 19 days in PBS at $\mathrm{pH}$ 7.4. CIP and PCL are both hydrophobic in nature and could interact among PCL chains chemically, as previously described..$^{44}$ Therefore, this could be the reason why the percentages of drug release observed in the present study did not reach 100\%, as CIP (hydrophobic drug) was trapped in a PCL (hydrophobic polymer) matrix that did not degrade over 19 days in the present study.

The immediate release of CIP entrapped within PCLCIP-NPs was observed 1 day after application of the AMF. The percentages of drug release (wt/wt) of PCL-CIP-NPs were significantly increased $(P<0.05$, two tailed, unpaired Student's $t$-test) at all time points under AMF by $\sim 27 \%$ in the PCL-CIP-maghemite group, except days 3, 5, 8, and 19 , whereas there was no statistically significant difference in the PCL-CIP-hematite group. The overall percentage of drug release from PCL-CIP-maghemite (AMF) was significantly greater than that from the PCL-CIP-hematite (AMF) $(P<0.05$, two tailed, unpaired Student's $t$-test $)$ at all time points by $\sim 35 \%$. These findings suggest that antibiotics carried by PCL-NP microspheres can be released with the application of an AMF. Therefore, this method of delivery can reduce the dose and frequency of antibiotic administration to inhibit 
infection. Moreover, antibiotics can be guided for delivery to the site of the orthopedic implant using a magnetic field.

\section{Conclusion}

The findings of the present study demonstrated that the release of CIP entrapped within the PCL-iron oxide NPs increased after application of an AMF due to the inhibition of $S$. aureus for 1 day, 2 days, and 5 days in vitro. CIP was immediately released from the PCL-CIP-NPs by applying an $\mathrm{AMF}$, and the release remained constant for up to 19 days. Drug release from the PCL-CIP-maghemite and the PCLCIP-hematite was enhanced by AMF compared with the same sample without applying an AMF by $\sim 27 \%(P<0.05)$ and $\sim 3 \%$ ( $P$ not significant), respectively. The chemically synthesized hematite $\left(\alpha-\mathrm{Fe}_{2} \mathrm{O}_{3}\right)$, maghemite $\left(\gamma-\mathrm{Fe}_{2} \mathrm{O}_{3}\right)$, and PCL-CIP-NPs used in the present study were biocompatible with fibroblasts and macrophages. The bacterial density decreased when the culture was incubated with the PCLCIP-NPs, regardless of the presence of the AMF, from days 1 to 5 of incubation. Moreover, drug release was increased under incubation with the application of AMF due to the enhanced suppression of bacterial growth in the presence of the PCL-CIP-NPs from days 1 to 5, compared with the same group without the application of AMF. Additional studies that focus on optimizing the effects of magnetic field strength are warranted. The use of iron oxide NPs for targeted delivery and stimulated release of drugs represents a promising alternative external control technique for effective antibiotic treatment.

\section{Acknowledgments}

The authors would like to thank Ms Mary Ellenburg for her technical assistance in bacteria inhibition study. This work was supported by the US Army Medical Research and Materiel Command under contract W81XWH-08-1-0333.

\section{Disclosure}

The authors report no conflicts of interest in this work.

\section{References}

1. Pankhurst QA, Connolly J, Jones SK, Dobson J. Applications of magnetic nanoparticles in biomedicine. J Phys D Appl Phys. 2003;36:R167-R181.

2. Berry CC, Curtis ASG. Functionalisation of magnetic nanoparticles for applications in biomedicine. J Phys D Appl Phys. 2003;36: R198-R206.

3. Moroz P, Jones SK, Gray BN. Magnetically mediated hyperthermia: current status and future directions. Int J Hyperthermia. 2002;18(4): 267-284.

4. Mahmoudi M, Simchi A, Milani AS, Stroeve P. Cell toxicity of superparamagnetic iron oxide nanoparticles. J Colloid Interface Sci. 2009; 336(2):510-518.
5. Coey JMD. Magnetism and Magnetic Materials. Cambridge: Cambridge University Press; 2010.

6. Hoare T, Santamaria J, Goya GF, et al. A magnetically triggered composite membrane for on-demand drug delivery. Nano Lett. 2009;9(10): 3651-3657.

7. Tai LA, Tsai PJ, Wang YC, Wang YJ, Lo LW, Yang CS. Thermosensitive liposomes entrapping iron oxide nanoparticles for controllable drug release. Nanotechnology. 2009;20(13):135101.

8. Muller-Schulte D, Schmitz-Rode T. Thermosensitive magnetic polymer particles as contactless controllable drug carriers. J Magn Magn Mater. 2006;302(1):267-271.

9. Zhang J, Misra RD. Magnetic drug-targeting carrier encapsulated with thermosensitive smart polymer: core-shell nanoparticle carrier and drug release response. Acta Biomater. 2007;3(6):838-850.

10. Hu S-H, Tsai C-H, Liao C-F, Liu D-M, Chen S-Y. Controlled rupture of magnetic polyelectrolyte microcapsules for drug delivery. Langmuir. 2008;24(20):11811-11818.

11. Hu S-H, Chen S-Y, Liu D-M, Hsiao C-S. Core/single-crystal-shell nanospheres for controlled drug release via a magnetically triggered rupturing mechanism. Adv Mater. 2008;20(14):2690-2695.

12. Hu S-H, Liu T-Y, Huang H-Y, Liu D-M, Chen S-Y. Magnetic-sensitive silica nanospheres for controlled drug release. Langmuir. 2007;24(1): 239-244.

13. Dilnawaz F, Singh A, Mohanty C, Sahoo SK. Dual drug loaded superparamagnetic iron oxide nanoparticles for targeted cancer therapy. Biomaterials. 2010;31(13):3694-3706.

14. Li R, Wu R, Zhao L, et al. Folate and iron difunctionalized multiwall carbon nanotubes as dual-targeted drug nanocarrier to cancer cells. Carbon N Y. 2011;49(5):1797-1805.

15. Subbiahdoss G, Sharifi S, Grijpma DW, et al. Magnetic targeting of surface-modified superparamagnetic iron oxide nanoparticles yields antibacterial efficacy against biofilms of gentamicin-resistant staphylococci. Acta Biomater. 2012;8(6):2047-2055.

16. Sirivisoot S, Pareta RA, Webster TJ. A conductive nanostructured polymer electrodeposited on titanium as a controllable, local drug delivery platform. J Biomed Mater Res A. 2011;99(4):586-597.

17. Sirivisoot S, Pareta R, Webster TJ. Electrically controlled drug release from nanostructured polypyrrole coated on titanium. Nanotechnology. 2011;22(8):085101.

18. Sirivisoot S, Harrison BS. Skeletal myotube formation enhanced by electrospun polyurethane carbon nanotube scaffolds. Int J Nanomedicine. 2011; 6:2483-2497.

19. Xu H, Cheng L, Wang C, Ma X, Li Y, Liu Z. Polymer encapsulated upconversion nanoparticle/iron oxide nanocomposites for multimodal imaging and magnetic targeted drug delivery. Biomaterials. 2011;32(35):9364-9373.

20. Wang S, Guo S, Cheng L. Disodium norcantharidate loaded poly([var epsilon]-caprolactone) microspheres: I. Preparation and evaluation. Int J Pharm. 2008;350(1-2):130-137.

21. Pitt CG. Poly( $\varepsilon$-caprolactone) and its copolymers. In: Chasin M, Langer R, editors. Biodegradable Polymer as Drug Delivery Systems. New York, NY: Marcel Decker Inc; 1990:71-120.

22. Kim SY, Lee YM. Taxol-loaded block copolymer nanospheres composed of methoxy poly(ethylene glycol) and poly( $\varepsilon$-caprolactone) as novel anticancer drug carriers. Biomaterials. 2001;22(13):1697-1704.

23. Lamprecht A, Torres HR, Schäfer U, Lehr C-M. Biodegradable microparticles as a two-drug controlled release formulation: a potential treatment of inflammatory bowel disease. J Control Release. 2000;69(3): $445-454$.

24. Lamprecht A, Ubrich N, Hombreiro Pérez M, Lehr C, Hoffman M, Maincent $\mathrm{P}$. Influences of process parameters on nanoparticle preparation performed by a double emulsion pressure homogenization technique. Int J Pharm. 2000;196(2):177-182.

25. Gristina AG. Biomaterial-centered infection: microbial adhesion versus tissue integration. Science. 1987;237(4822):1588-1595.

26. Khalil H, Williams RJ, Stenbeck G, Henderson B, Meghji S, Nair SP. Invasion of bone cells by Staphylococcus epidermidis. Microbes Infect. 2007; 9(4):460-465. 
27. Stratton C. Fluoroquinolone antibiotics: properties of the class and individual agents. Clin Ther. 1992;14(3):348-375.

28. Jeong YI, Na HS, Seo DH, et al. Ciprofloxacin-encapsulated poly(DLlactide-co-glycolide) nanoparticles and its antibacterial activity. Int J Pharm. 2008;352(1-2):317-323.

29. Armstrong EP, Friedman AD. Bone and joint infections. In: DiPiro JT, Talbert RL, Yee GC, et al, editors. Pharmacotherapy: A Pathophysiologic Approach. 8th ed. New York, NY: McGraw-Hill; 2011: 2029-2039.

30. Lew DP, Waldvogel FA. Use of quinolones in osteomyelitis and infected orthopaedic prosthesis. Drugs. 1999;58(Suppl 2):85-91.

31. Clinical and Laboratory Standards Institute. Performance Standards for Antimicrobial Susceptibility Testing; Sixteenth Informational Supplement. Wayne, PA: Clinical and Laboratory Standards Institute; 2006. CLSI document M100-S16 [ISBN 1-56238-625-5].

32. Wiegand I, Hilpert K, Hancock RE. Agar and broth dilution methods to determine the minimal inhibitory concentration (MIC) of antimicrobial substances. Nat Protoc. 2008;3(2):163-175.

33. Pascual-Reguera MI, Parras GP, Diamp AM. Solid-phase UV spectrophotometric method for determination of ciprofloxacin. Microchem J. 2004;77(1):79-84.

34. Kang YS, Risbud S, Rabolt JF, Stroeve P. Synthesis and characterization of nanometer-size Fe3O4 and $\gamma$-Fe2O3 particles. Chem Mater. 1996;8: 2209-2211.

35. Bee A, Massart R, Neveu S. Synthesis of very fine maghemite particles. J Magn Magn Mater. 1995;149:6-9.

36. Lode H. Evidence of different profiles of side effects and drug-drug interactions among the quinolones - the pharmacokinetic standpoint. Chemotherapy. 2001;47(Suppl 3):24-31. [discussion 44-48].

37. Masadeh MM, Karasneh GA, Al-Akhras MA, et al. Cerium oxide and iron oxide nanoparticles abolish the antibacterial activity of ciprofloxacin against gram positive and gram negative biofilm bacteria. Cytotechnology. 2015;67(3):427-435.
38. He S, Feng Y, Gu N, Zhang Y, Lin X. The effect of $\gamma$-Fe2O3 nanoparticles on Escherichia coli genome. Environ Pollut. 2011;159(2): 3468-3473.

39. Azam A, Ahmed AS, Oves M, Khan MS, Habib SS, Memic A. Antimicrobial activity of metal oxide nanoparticles against Grampositive and Gram-negative bacteria: a comparative study. Int J Nanomedicine. 2012;7:6003-6009.

40. Rakshit S, Sarkar D, Elzinga EJ, Punamiya P, Datta R. Mechanisms of ciprofloxacin removal by nano-sized magnetite. J Hazard Mater. 2013;24(6-247):221-226.

41. Tang Y, Guo H, Xiao L, Yu S, Gao N, Wang Y. Synthesis of reduced graphene oxide/magnetite composites and investigation of their adsorption performance of fluoroquinolone antibiotics. Colloids Surf A Physicochem Eng Asp. 2013;424:74-80.

42. Woodruff MA, Hutmacher DW. The return of a forgotten polymer polycaprolactone in the 21st century. Prog Polym Sci. 2010;35: 1217-1256.

43. Sinha VR, Bansal K, Kaushik R, Kumria R, Trehan A. Poly-e-caprolactone microspheres and nanospheres: an overview. Int J Pharm. 2004;1(18): $1-23$.

44. Bosworth LA, Downes S. Physicochemical characterization of degrading polycaprolactone scaffolds. Polym Degrad Stab. 2010;95: 2269-2276.

45. Sobczak M. Synthesis and characterization of polyester conjugates of ciprofloxacin. Eur J Med Chem. 2010;45:3844-3849.

46. Puga AM, Rey-rico A, Magarinos B, Alvarez-Lorenzo C, Concheiro A. Hot melt poly-e-caprolactone/poloxamine implantable matrices for sustained delivery of ciprofloxacin. Acta Biomater. 2012;8(4): 1507-1518.

47. Lam CXF, Teoh SH, Hutmacher DW. Comparison of the degradation of polycaprolactone and polycaprolactone-(beta-tricalcium phosphate) scaffolds in alkaline medium. Polym Int. 2007;56:718-728.
International Journal of Nanomedicine

\section{Publish your work in this journal}

The International Journal of Nanomedicine is an international, peerreviewed journal focusing on the application of nanotechnology in diagnostics, therapeutics, and drug delivery systems throughout the biomedical field. This journal is indexed on PubMed Central, MedLine, CAS, SciSearch $®$, Current Contents ${ }^{\circledR} /$ Clinical Medicine,

\section{Dovepress}

Journal Citation Reports/Science Edition, EMBase, Scopus and the Elsevier Bibliographic databases. The manuscript management system is completely online and includes a very quick and fair peer-review system, which is all easy to use. Visit http://www.dovepress.com/ testimonials.php to read real quotes from published authors. 